\title{
Hepatitis B-DNA replication and histological patterns in liver biopsy specimens of chronic HBsAg positive patients with and without hepatitis delta virus superinfection
}

\author{
DANIELA VILLARI, * G RAIMONDO, V SMEDILE, GIUSEPPINA RODINÓ, \\ SANTA BRANCATELLI, G LONGO, G SQUADRITO, D BATOLO*
}

From the *Department of Human Pathology, and the Institute of Internal Medicine, Policlinico Universitario di Messina, Messina, Italy

SUMMARY The role of active hepatitis B virus (HBV) infection in chronic HBsAg positive hepatitis with and without hepatitis delta virus (HDV) superinfection was analysed in percutaneous liver biopsy specimens from 50 patients. Each specimen was divided into two-one part for histological evaluation and for the detection of $\mathrm{HBcAg}$ and delta antigen; the other part was tested for HBVDNA using Southern blotting. Ten cases were of chronic lobular hepatitis, 10 of chronic persistent hepatitis, and 30 of chronic active hepatitis. Ten cases were delta antigen positive and showed high grade lobular activity but no evidence of HBV-DNA episomal forms or HBcAg reactivity. Twenty one cases showed HBV-DNA replicative intermediate forms; 19 had high grade lobular activity, which occurred in five cases without evidence of free viral DNA. Of the 21 biopsy specimens with HBV-DNA episomal forms, 14 were positive for $\mathrm{HBcAg}$; only one of the 19 cases without detectable viral DNA was positive for such antigen.

These data indicate that the presence of HBV or HDV active infection correlates with the histological finding of prominent lobular necrosis. Moreover, intrahepatic HBV-DNA seems to be a more sensitive marker than the presence of viral antigens for indicating HBV replication.

Hepatic damage in chronic carriers of hepatitis B surface antigen (HBsAg) seems to be strictly related to the presence of hepatitis B virus (HBV) active infection or delta virus (HDV) superinfection. ${ }^{1-6}$

In most of the studies performed so far active replication of HBV has been evaluated by immunohistochemical detection of hepatitis $B$ core antigen $(\mathrm{HBcAg})$ in liver tissue and using serological markers. ${ }^{378}$ The development of molecular biological techniques has allowed specific HBV-DNA sequences in liver biopsy specimens to be detected, thus providing direct evidence of $\mathrm{HBV}$ replication. ${ }^{19}$

This study aimed to investigate the association between the presence of HBV-DNA episomal forms and the different patterns of histological activity within the liver tissue of chronic $\mathrm{HBsAg}$ positive patients with and without HDV superinfection. We also compared the results of the molecular analysis

Accepted for publication 19 January 1989 with the immunohistochemical markers of viral activity.

\section{Material and methods}

Percutaneous liver biopsy specimens from 50 chronic HBsAg carriers consecutively admitted to hospital between 1983 and 1987 were studied. Thirteen of them were positive for hepatitis $\mathrm{B}$ e antigen $(\mathrm{HBeAg})$ and 37 for the corresponding antibodies (anti-HBe); 11 $\mathrm{HBeAg}$ and five anti-HBe patients had HBV-DNA in their serum. None was found to be positive for IgM antibodies to $\mathrm{HBcAg}$ (IgM anti-HBc), indicating chronic HBV infection. Ten patients were positive for antibodies to delta antigen.

Serological markers of HBV and HDV infection were measured by commercial radioimmunoassays (AUK 3, AB AUK 3, CORE IGMK, AB DELTA, Sorin Biomedica, Saluggia, Italy). Serum HBV-DNA was detected by a molecular hydridisation technique, as previously described. ${ }^{10}$ 


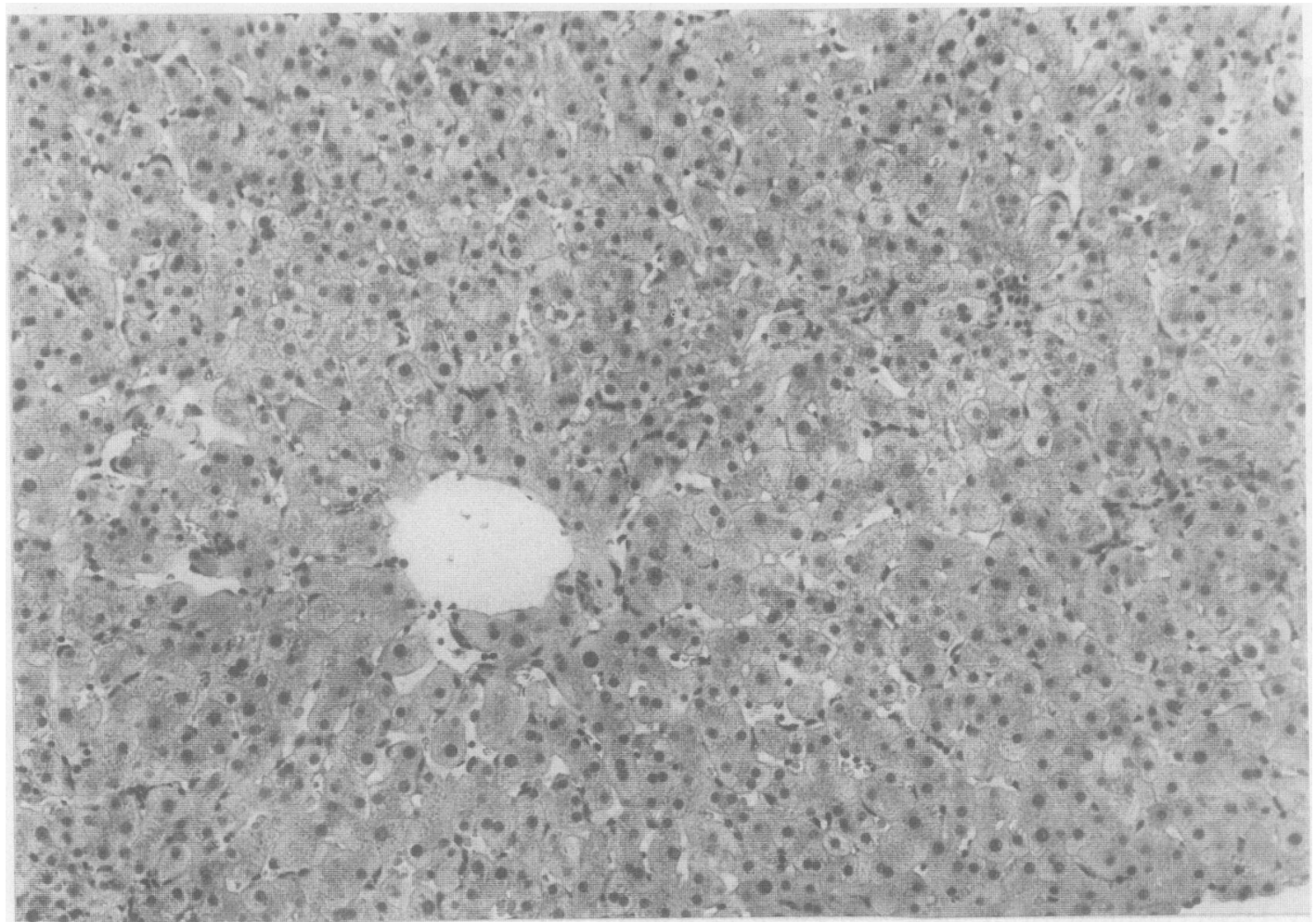

Fig 1 An example of low lobular activity. Few inflammatory infiltrates are present in this lobule. (Haematoxylin and eosin.)

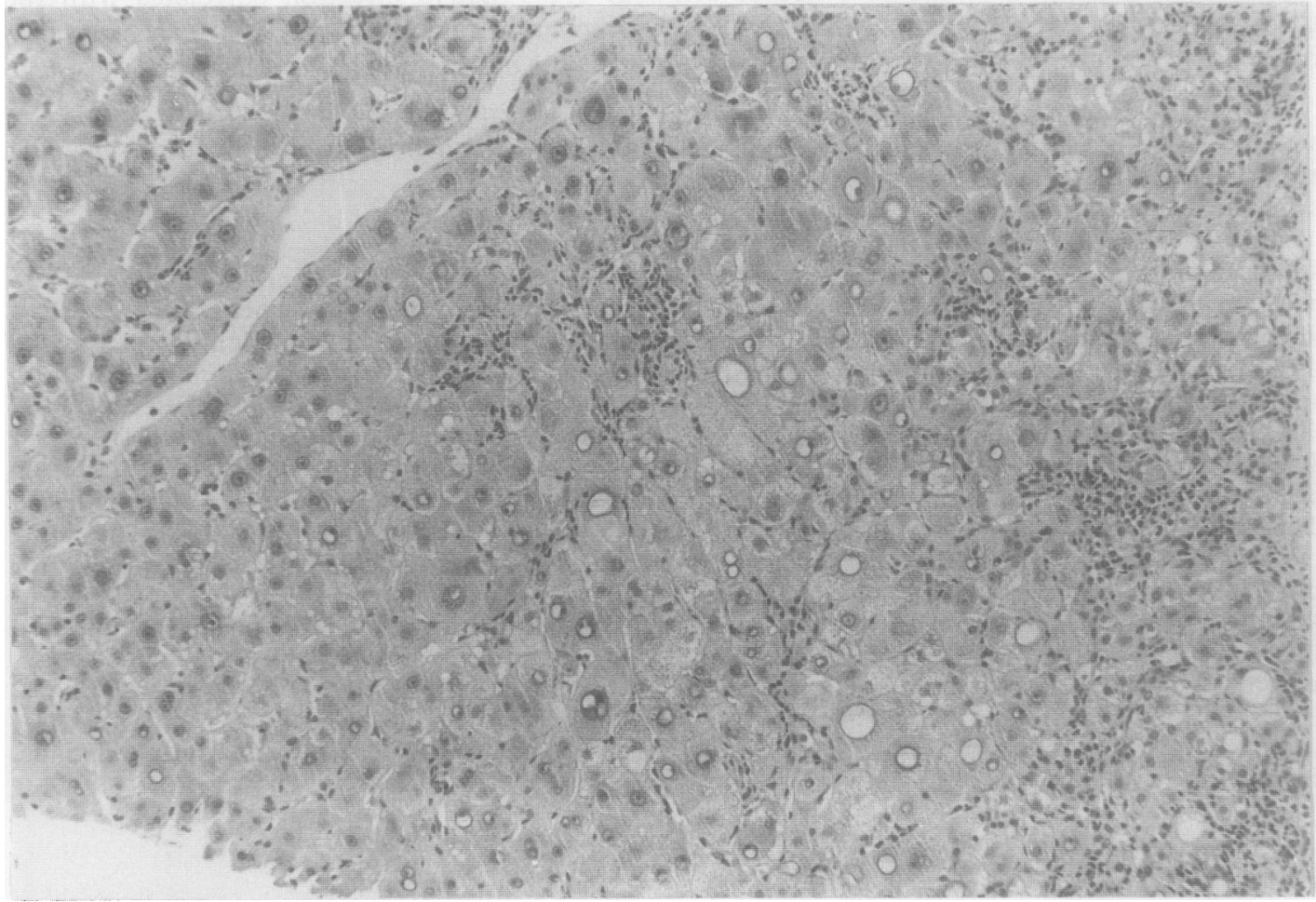

Fig 2 An example of high lobular activity. Inflammatory infiltrates and degenerative changes are visible in the lobule. (Haematoxylin and eosin.) 
None of the patients had ever been treated with antiviral or immunosuppressive drugs.

Each liver biopsy sample was divided into two parts: one was fixed in formalin and embedded in paraffin wax for histological and immunohistochemical evaluation; the other was immediately frozen and stored at $-70^{\circ} \mathrm{C}$ until further molecular analysis. The specimens were stained with haematoxylin and eosin and the diagnosis was made according to generally accepted criteria." The degree of lobular activity was evaluated by analysing mesenchymal cell reaction, foci of necrosis, inflammatory infiltrates and degenerative and regenerative liver cell changes. The presence of only a few foci of necrosis and the absence of cellular changes were regarded as indicative of a low degree of lobular activity (fig 1). Foci of inflammatory necrosis were indicative of a high degree of lobular activity and cellular modifications observed in each lobule (fig 2).

Immunoperoxidase staining for $\mathrm{HBcAg}$ and delta antigen was done on paraffin wax sections of each liver biopsy specimen; for $\mathrm{HBcAg}$ a peroxidase-anti-peroxidase kit was used (HBcAg PAP kit system, Dako Corporation, Santa Barbara, California, USA); delta antigen was detected by a peroxidase labelled specific antiserum, kindly donated by Drs M Rizzetto and C Lavarini.

For hybridisation, DNA was extracted from tissue and analysed by the Southern blot technique, as previously described ${ }^{12}$; in brief, liver biopsy specimens were homogenised in $150 \mathrm{mM} \mathrm{NaCl}$ and $50 \mathrm{mM}$ Tris$\mathrm{HCl}(\mathrm{pH} 7 \cdot 4)$ and $10 \mathrm{mM}$ EDTA $0 \cdot 1 \%$ sodium dodecyl sulphate and incubated overnight with proteinase $\mathrm{K}$ $(800 \mu \mathrm{g} / \mathrm{ml})$ at $37^{\circ} \mathrm{C}$. After extraction with phenol: chloroform $(1: 1 \mathrm{v} / \mathrm{v})$ the nucleic acid was precipitated

Table 1 Histological patterns in liver biopsy specimens from 50 chronic $\mathrm{HBs} \mathrm{Ag}$ positive patients

\begin{tabular}{llll}
\hline & $\begin{array}{l}\text { Total } \\
\text { No of } \\
\text { cases }\end{array}$ & $\begin{array}{l}\text { High grade } \\
\text { lobular } \\
\text { necrosis }\end{array}$ & $\begin{array}{l}\text { Low grade } \\
\text { lobular } \\
\text { necrosis }\end{array}$ \\
\hline Group 1 & 10 & 10 & 0 \\
Group 2 & 10 & 0 & 10 \\
Group 3 & 30 & 23 & 7 \\
\hline
\end{tabular}

in three volumes of pure cold ethanol. The nucleic acid was resuspended and digested with pancreatic ribonuclease $(100 \mu \mathrm{g} / \mathrm{ml})$, followed by digestion with proteinase $\mathrm{K}(100 \mu \mathrm{g} / \mathrm{ml})$, extraction with phenol: chloroform and reprecipitation in pure cold ethanol. The DNA was resuspended in $10 \mathrm{mM}$ Tris- $\mathrm{HCl}(\mathrm{pH}$ 7.4) - 1 mM EDTA, and the concentration of nucleic acid in solution was determined by spectrophotometry at $260 \mathrm{~nm}$; after digestion with restriction endonuclease Hind III 10-15 $\mu \mathrm{g}$ of DNA were electrophoressed through $0.8 \%$ agarose gel. The separated DNA was transferred to nicrocellulose filter sheets and the filters baked for two hours at $80^{\circ} \mathrm{C}$. The filters were prehybridised with $5 x$ SSC- $0.1 \%$ sodium dodecyl sulphate- $50 \%$ formamide- $0 \cdot 1 \%$ Denhardt's solution and denatured salmon sperm DNA $(200 \mu \mathrm{g} / \mathrm{ml})$ at $42^{\circ} \mathrm{C}$ overnight, and then hybridised under similar conditions for 16 hours using double stranded, cloned repurified HBV-DNA (3200 base pairs). Purified HBV-DNA was labelled with $32 \mathrm{P}$ to high specificity $\left(2-4 \times 10^{8} \mathrm{cpm} / \mu \mathrm{g}\right.$ DNA) by using primer extension, as described by Summers. ${ }^{13}$ After hybridisation the nitrocellulose filter was washed, dried, and autoradiographed.

\section{Results}

Of the 50 cases examined, $10(20 \%)$ had chronic lobular hepatitis (group 1), $10(20 \%)$ had chronic persistent hepatitis (group 2), and $30(60 \%)$ had chronic active hepatitis (group 3) (table 1).

The evaluation of the lobular activity showed high grade necrosis and inflammation in all group 1 cases and in 23 group 3 cases (table 1). Ten cases, three group 1 and seven group 3, were positive for delta antigen, and all showed high grade lobular activity; none of them showed HBV-DNA or $\mathrm{HBcAg}$ reactivity (tables 1-3). HBV-DNA replicative forms were found in 21 cases (five group 1, 16 group 3) (fig 3), and 19 showed high grade lobular activity; $\mathrm{HBcAg}$ was detected in 14 of these cases (tables 1-3) with an exclusively nuclear reactivity in 10 and nuclear and cytoplasmic staining in four.

Nineteen liver biopsy specimens were negative for

Table 2 Markers of active $\mathrm{HBV}$ and HDV replication in liver tissue of 33 chronic $\mathrm{HBs}$ Ag positive cases with high grade lobular activity

\begin{tabular}{|c|c|c|c|c|c|}
\hline & ${ }^{*}$ Delta antigen ${ }^{+}$ & $\begin{array}{l}+H B V-D N A^{+} \\
H B c A g^{+}\end{array}$ & $\begin{array}{l}+H B V-D N A^{+} \\
H B C A g^{-}\end{array}$ & $\begin{array}{l}+H B V-D N A^{-} \\
H B c A g^{+}\end{array}$ & $\begin{array}{l}+H B V-D N A^{-} \\
H B c A g^{-}\end{array}$ \\
\hline $\begin{array}{l}\text { Group } 1 \\
\text { Group } 2 \\
\text { Group } 3\end{array}$ & $\begin{array}{l}3 \\
0 \\
7\end{array}$ & $\begin{array}{r}4 \\
0 \\
10\end{array}$ & $\begin{array}{l}1 \\
0 \\
4\end{array}$ & $\begin{array}{l}\mathbf{0} \\
\mathbf{0} \\
\mathbf{0}\end{array}$ & $\begin{array}{l}2 \\
0 \\
2\end{array}$ \\
\hline
\end{tabular}

*HBcAg and HBV-DNA negative.

+ Replicative intermediate forms.

negative, ${ }^{+}$positive. 
Table 3 Markers of active HBV and HDV replication in liver tissue of 17 chronic HBsAg positive cases with low grade lobular activity

\begin{tabular}{|c|c|c|c|c|c|}
\hline & * Delta antigen ${ }^{+}$ & $\begin{array}{l}+H B V-D N A^{+} \\
H B c A g^{+}\end{array}$ & $\begin{array}{l}+H B V-D N A^{+} \\
H B c A g^{-}\end{array}$ & $\begin{array}{l}+H B V-D N A^{-} \\
H B c A g^{+}\end{array}$ & $\begin{array}{l}+H B V-D N A^{-} \\
H B C A g^{-}\end{array}$ \\
\hline $\begin{array}{l}\text { Group } 1 \\
\text { Group } 2 \\
\text { Group } 3\end{array}$ & $\begin{array}{l}0 \\
0 \\
0\end{array}$ & $\begin{array}{l}0 \\
0 \\
0\end{array}$ & $\begin{array}{l}0 \\
0 \\
2\end{array}$ & $\begin{array}{l}0 \\
0 \\
1\end{array}$ & $\begin{array}{r}0 \\
10 \\
4\end{array}$ \\
\hline
\end{tabular}

delta antigen and HBV-DNA (two group 1, 10 group 2 , seven group 3 ) and only one of them was positive for $\mathrm{HBcAg}$ with a pattern of nuclear and focal reactivity; 15 of these 19 cases showed low grade of lobular activity (table 3). All 16 patients seropositive for HBVDNA showed free viral forms in the liver; 13 of these cases were positive and three negative for $\mathrm{HBcAg}$.

\section{Discussion}

The detection of markers for HBV and HDV infection in liver tissue seems to be the best way of identifying active viral replication. The determination of conventional serological markers gives only indirect information about the state of infection, and the detection of specific nucleic acid sequences in the serum can be misleading because viraemia often fluctuates.

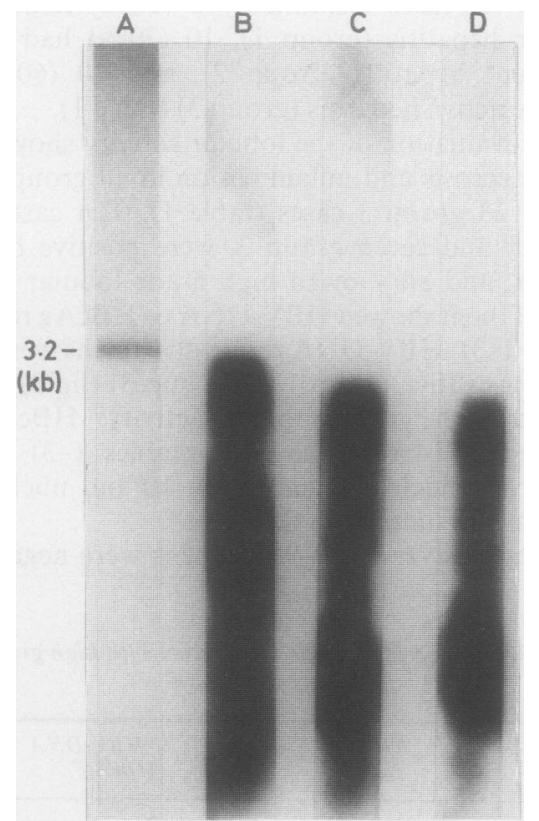

Fig 3 Southern blot hybridisation analysis for $H B V-D N A$ sequences in total DNA extracts from three percutaneous liver biopsy specimens (lanes $B-D$ ) showing typical pattern of $H B V-D N A$ replication. The diographic band in lane $A$ marks the position of $3 \cdot 2$ kilobase linear $H B V-D N A$.
HDV is a defective virus with a putative RNA genome whose replication requires the helper function of $\mathrm{HBV}{ }^{6}$ The examination of liver biopsy specimens for HDV-DNA still presents some problems, because of the difficulty of preserving the RNA properly and also because the amount of the RNA obtained from small fractions of tissue is often not sufficient for the test. The best method, therefore, for the diagnosis of active HDV infection remains finding delta antigen in the liver tissue. On the other hand, molecular hybridisation techniques have been successfully used to detect HBV-DNA sequences in liver specimens ${ }^{191214}$ and they give clinically important information about the HBV infection.

Ten of the cases studied were positive for delta antigen in the liver. Because the pathogenecity of delta virus probably results from direct cell damage, it is not surprising that in all the delta positive biopsy specimens that we studied pronounced lobular necrosis was observed. Moreover, there is strong evidence to suggest that delta virus infection plays an important part in aggravating liver disease in chronic HBsAg carriers; seven of our HDV positive patients had severe chronic hepatitis. ${ }^{46}$ The other three patients with delta antigen in their livers had chronic lobular hepatitis: in these subjects delta virus superinfection may be a recent event and the disease might progress to a more severe form of chronic hepatitis. ${ }^{4}$ The absence of $\mathrm{HBcAg}$ and HBV-DNA episomal forms in the liver tissue of such patients confirms that HDV inhibits HBV replication. ${ }^{1516}$

Of the 40 biopsy specimens negative for delta antigen, 21 showed replication of intermediate forms of HBV-DNA; only 14 of them were also positive for HBcAg. These data seem to show that the analysis of hepatic DNA is more sensitive than the study of viral antigens for showing active HBV replication. The inhibition of production of core proteins may be the first step in a process which eventually halts active HBV-DNA replication. ${ }^{17}$

As we observed in the liver biopsy specimens positive for delta antigen, the presence of intrahepatic HBV-DNA replicative forms seems to be associated only with the histological finding of high grade lobular activity. In fact, 19 of 21 cases with HBV-DNA free forms showed prominent necrosis, while in 15 of the 19 
cases in which the HBV-DNA was absent, none or very few necrotic foci were observed. These data indicate that necrosis in chronic HBV hepatitis is related to the formation of complete virion particles, even if hepatocyte injury is probably mediated by host immune response.

Recent observations suggest that mild forms of chronic hepatitis may progress to more severe chronic disease if active viral replication persists. ${ }^{418}$ In chronic $\mathrm{HBsAg}$ positive patients, therefore, the analysis of liver biopsy specimens for HBV and HDV markers of active infection seems to be helpful for correct diagnosis, prognosis, and appropriate management.

\section{We thank Mr Angelo Macri and Mrs Lucia Giacoppo} for their assistance.

\section{References}

1 Hadziyannis SJ, Lieberman HM, Karvountzis GG, Shafritz DA. Analysis of liver disease, nuclear $\mathrm{HBcAg}$, viral replication and heptatits B virus DNA in liver and serum of $\mathrm{HBeAg}$ Vs. anti$\mathrm{HBe}$ positive carriers of hepatitis B virus. Hepatology 1983;3:656-62.

2 Bonino F, Rosina F, Rizzetto M, et al. Chronic hepatitis in $\mathrm{HBsAg}$ carriers with serum HBV-DNA and anti-HBe. Gastroenterology 1986;90:1268-73.

3 Ramalbo F, Brunetto MR, Rocca FG, et al. Serum markers of hepatitis $B$ virus replication, liver histology and intrahepatic expression of hepatitis B core antigen. $J$ Hepatol 1988;7:14-20.

4 Rizzetto M, Verme G, Recchia S, et al. Chronic hepatitis in carriers of hepatitis B surface antigen with intrahepatic expression of the delta agent. Ann Int Med 1983;98:437-41.

5 Craxi A, Raimondo G, Longo G, et al. Delta agent infection in acute hepatitis and chronic HBsAg carriers with and without liver disease. Gut 1984;25:1288-90.

6 Rizzetto M, Verme G. Delta hepatitis: present status. J Hepatol 1985;1:187-93.
7 Chu CM, Liaw YF. Intrahepatic distribution of hepatitis B surface and core antigens in chronic hepatitis $B$ virus infection. Gastroenterology 1987;92:220-5.

8 Yoo JY, Howard R, Waggoner JG, Hoffnagle JH. Peroxidaseanti-peroxidase detection of hepatitis $B$ surface and core antigens in liver biopsy specimens from patients with chronic type B hepatitis. J Med Virol 1987;23:273-81.

9 Bonino F. The importance of hepatitis B viral DNA in serum and liver. J Hepatol 1986;3:136-41.

10 Lieberman HM, LaBrecque DR, Kew MC, Hadziyannis SJ, Shafritz DA. Detection of hepatitis B virus DNA in human serum by a simplified molecular hybridisation test: comparison to $\mathrm{HBeAg} /$ anti-HBe status in $\mathrm{HBsAg}$ carriers. Hepatology 1983;3:285-91.

11 Phillips MJ, Poucell S. Modern aspects of the morphology of viral hepatitis. Hum Pathol 1981;12:1060-84.

12 Shafritz DA, Shouval D, Sherman HI, Hadziyannis SJ, Kew MC. Integration of hepatitis B virus DNA into the genoma of liver cells in chronic liver disease and hepatocellular carcinoma. $N$ Engl J Med 1981;305:1067-73.

13 Summers J. Physical map of polyoma viral DNA fragments produced by cleavage with a restriction enzyme from Haemophilus aegyptius endonuclease R Hae III. J Virol 1975;15: 946-53.

14 Brechot C, Hadchouel M, Scott J, et al. Detection of hepatitis B virus DNA in liver and serum: a direct appraisal of the chronic carrier state. Lancet 1981;ii:765-8.

15 Negro F, Chaberge E, Olivero S, et al. Hepatitis B virus DNA (HBV-DNA) in anti-HBe positive sera. Liver 1994;4:177-83.

16 Hadziyannis SJ, Sherman M, Lieberman HM, Shafritz DA. Liver disease activity and hepatitis $B$ virus replication in chronic delta antigen positive B virus carriers. Hepatology 1985;5:544-8.

17 Raimondo G, Burk RD, Lieberman HM, et al. Interrupted replication of hepatitis B virus in liver tissue of $\mathrm{HBsAg}$ carriers with hepatocellular carcinoma. Virology 1988;166:103-12.

$18 \mathrm{Paz}$ MOA, Brenes F, Karayiannis P, et al. Chronic hepatitis B virus infection. $J$ Hepatol 1986;3:371-7.

Requests for reprints to: Dott. Giovanni Raimondo, Istituto di Medicina Interna, Policlinico Universitario, Via Consolare Valeria, 98100 Messina, Italy. 